\title{
STRATEGI PENGUATAN FUNGSI KELUARGA PADA ERA PANDEMI COVID-19
}

\author{
I DEWA MADE SUKA \\ Widyaiswara Perwakilan BKKBN Provinsi Bali \\ e-mail: dewanandasuka@gmail.com
}

\begin{abstract}
ABSTRAK
Pandemi Covid-19 sudah berlangsung cukup lama, sejak Presiden Jokowi mengumumkan kasus Covid-19 pertama kali, pada tanggal 2 Maret 2020 silam. Sampai saat ini, masyarakat Indonesia yang terkonfirmasi virus corona terus meningkat, jumlah pasien yang sembuh terus bertambah, mereka yang mengalami kematian karena terpapar Covid-19 juga banyak. Penelitian ini berfokus kepada upaya meningkatkan fungsi keluarga sebagai lembaga terkecil dalam masyarakat yang bertujuan untuk meminimalisir jumlah anggota keluarga yang terpapar Covid-19. Adapun pendekatan penelitian yang penulis gunakan adalah studi kepustakaan, yaitu dengan mengumpulkan berbagai literatur dari berbagai sumber ilmiah yang ada. Simpulan dari pembahasan yang penulis lakukan adalah bahwa strategi penguatan fungsi keluarga menjadi mendesak untuk dilakukan sehingga dapat meminimalisir dan meningkatkan kewaspadaan keluarga dan masyarakat dari keterpaparan Virus Corona.
\end{abstract}

Kata Kunci: Strategi, Fungsi Keluarga, Covid-19

\section{PENDAHULUAN}

Sampai hari ini, tanda-tanda berakhirnya penyebaran virus corona, belum terlihat. Bahkan tren keterpaparan virus tersebut, semakin banyak. Kasus Covid-19 di Indonesia, pertama kali diumumkan Presiden Joko Widodo bersama Menteri Kesehatan Terawan Agus Putranto saat itu, bertempat di Istana Kepresidenan Jakarta, pada tanggal 2 Maret 2020. Adalah warga Negara Jepang yang berdomisili di Malaysia, sempat datang ke Indonesia, dan sekembalinya dari Indonesia dinyatakan positif corona. Tracking kemudian dilakukan oleh pemerintah, dan mendapati bahwa Warga Negara Jepang tersebut sudah kontak dengan seorang perempuan 31 tahun dan ibunya berusia 64 tahun. Tes terhadap anak dan ibunya tersebut juga dilakukan, dan dinyatakan positif covid-19.

Berbagai upaya sudah dilakukan pemerintah dan masyarakat, untuk mengurangi atau meminimalisir keterpaparan masyarakat dari virus yang mematikan tersebut. Di samping penanganan melalui pengobatan dan vaksinasi, juga diperlukan pencegahan.

Pencegahan terhadap virus corona mengandung arti mengikhtiarkan supaya tidak terpapar virus corona. Pencegahan mengandung makna esensial agar diri, keluarga dan orang lain selamat dari paparan Covid-19. Pencegahan merupakan tahapan awal penanggulangan Covid-19. Kesuksesan keluarga dan anggotanya, supaya sedini mungkin memahami upaya pencegahan virus corona, akan membuat paparan virus tersebut, menjadi landai, sehingga cukup tersedia rumah sakit rujukan, dokter dan tenaga medis lainnya untuk merawat. "mencegah lebih baik daripada mengobati", kata pepatah.

Salah satu institusi yang cukup efektif untuk melakukan pencegahan tersebut adalah keluarga. Menurut Undang-undang No. 52 tahun 2009, Keluarga diartikan sebagai unit terkecil dalam masyarakat yang terdiri dari suami istri, atau suami, istri dan anaknya, atau ayah dan anaknya, atau ibu dan anaknya. Departemen Kesehatan RI menyatakan bahwa keluarga merupakan unit terkecil dari masyarakat yang terdiri dari kepala keluarga dan beberapa orang yang berkumpul dan tinggal di suatu tempat di bawah satu atap dalam keadaan saling ketergantungan (Departemen Kesehatan RI : 1988).

Dengan demikian, keluarga memiliki fungsi utama untuk menghindarkan seluruh anggota keluarganya agar terhindar dari paparan Virus Corona Deseas 2019 yang disingkat menjadi Covid-19. Keluarga dapat bersinergi dengan berbagai intitusi lainnya di masyarakat untuk melakukan pencegahan dari keterpaparan virus corona. Nilai baru penelitian ini adalah 
melibatkan peran keluarga sebagai unit terkecil dalam masyarakat, untuk aktif melakukan pencegahan di tingkat keluarga. Kalau anggota keluarga sehat dan selamat dari paparan Covid19, niscaya akan berpengaruh kepada kesehatan masyarakat secara luas. Di sinilah perlu dibahas tentang fungsi-fungsi keluarga yang perlu dikuatkan lagi, terlebih adanya pandemi virus corona yang melanda dunia saat ini.

\section{METODE PENELITIAN}

Penelitian Kepustakaan atau sering juga disebut dengan studi pustaka ialah serangkaian kegiatan yang berkaitan dengan metode pengumpulan data pustaka, membaca dan mencatat serta mengolah bahan penelitian. Setidaknya ada empat ciri utama penelitian kepustakaan yang perlu diperhatian. Keempat ciri itu akan mempengaruhi sifat dan cara kerja penelitian.

Ciri pertama adalah bahwa peneliti berhadapan langsung dengan teks atau data atau angka atau gabungan semuanya dan bukan dengan pengetahuan langsung dari lapangan atau saksi mata (eyewitness) berupa orang, kejadian atau benda-benda lainnya. Ciri yang kedua, data pustaka bersifat 'siap pakai' ( ready made). Artinya, peneliti tidak pergi kemana-mana. Kecuali hanya berhadapan langsung dengan bahan sumber yang sudah tersedia di perpustakaan. Satusatunya cara untuk belajar menggunakan perpustakaan dengan tepat adalah dengan langsung menggunakannya.

Ciri yang ketiga ialah bahwa data pustaka umumnya adalah sumber sekunder, dalam arti bahwa peneliti memperoleh bahan dari tangan kedua dan bukan data orisinil dari tangan pertama di lapangan. Ciri yang keempat adalah bahwa kondisi data pustaka tidak dibatasi oleh ruang dan waktu. Artinya, kapan saja ia datang dan pergi, data tersebut tidak akan pernah berubah, karena ia sudah merupakan data yang tersimpan dalam rekaman data yang tertulis (teks, angka, gambar, rekaman tape atau film). Tetapi, nilai tambah yang bisa kita dapatkan, bahwa jenis penelitian apapun digunakan oleh seorang peneliti tidak bisa mengabaikan arti dan makna kepustakaan.

Penulis menggunakan metode kepustakaan ini, dengan prosedur yang sudah disiapkan terlebih dahulu. Pertama, penulis membuat catatan pendukung untuk mengklasifikasikan referensi yang dibutuhkan, seperti buku, jurnal, koran, ataupun hasil penelitian terdahulu. Tiap literatur yang dibaca, penulis lakukan pencatatan point-point pentingnya, dan mengumpulkan dalam sebuah dokumen. Sumber bahan bacaan dituliskan bersamaan dengan pengumpulan tiaptiap dokumen tersebut. Klasifikasi juga penulis lakukan berdasarkan urutan nama penulis dan atau tahun terbit dari studi pustaka tersebut.

Hasil dari kegiatan membaca literatur tersebut penulis tuangkan dalam kertas tersendiri, bisa berupa kutipan langsung, kutipan tidak langsung ataupun paraprase, tetapi tetap dengan menuliskan sumber kutipan tersebut. Setelah terkumpul catatan yang diperlukan, dan representatif untuk mendukung dan mencarikan solusi atas masalah yang diangkat, penulis kemudian melakukan pengolahan data dari sumber bacaan tersebut. Dari pengolahan tersebut, dilakukan penyusunan yang dilanjutkan dengan penulisan secara keseluruhan dengan berpedoman pada template yang ada.

\section{HASIL DAN PEMBAHASAN}

Penelitian ini bersumber dari bahan bacaan yang penulis susun untuk mendapatkan jawaban atas permasalahan yang diangkat. Permasalahan diartikan sebagai kesenjangan antara harapan dengan kenyataan. Kenyataan saat ini, masih terdapat penduduk yang terpapar virus corona deseas 2019 atau disingkat Covid-19. Sehingga memerlukan penanganan kesehatan yang terintegrasi dan serius. Tenaga kesehatan ada di garda terdepan untuk mengawal kesehatan penduduk. Sinergitas sangat diperlukan dengan berbagai institusi, salah satunya adalah institusi terkecil dalam masyarakat, yaitu keluarga. Pada lembaga keluarga inilah harapan besar kita, agar bisa melakukan pencegahan secara massif. Sehingga semakin dapat diminimalisir angka kesakitan karena terpapar virus corona. Dengan demikian kesembuhan, kesehatan menjadi harapan kita, dan itu dapat terjadi dimulai dari keluarga masing-masing. 


\section{Hasil}

Keluarga adalah satuan unit terkecil dalam masyarakat yang terdiri atas, bapak dan ibu, bapak dan anak, ibu dan anak, juga bisa terdiri dari bapak, ibu, dan anak-anaknya. Sedangkan keluarga sejahtera adalah keluarga yang dibentuk atas perkawinan yang sah, mampu memenuhi kebutuhan hidup material maupun spiritual yang layak, memiliki hubungan serasi antar dan inter anggotanya.

Rumusan lain juga menyatakan bahwa keluarga sejahtera adalah keluarga yang dapat memenuhi kebutuhan anggotanya, baik kebutuhan sandang, pangan, perumahan, sosial dan agama, keluarga yang mempunyai keseimbangan antara penghasilan keluarga dengan jumlah anggota keluarga, juga keluarga yang dapat memenuhi kesehatan anggota keluarganya (BKKBN : 2017). Keluarga sejahtera ternyata memiliki tujuan yang hampir sama dengan pengertian keluarga berkualitas.

Dalam Undang-Undang RI Nomor 52 tahun 2009 tentang Perkembangan Kependudukan dan Pembangunan Keluarga, menyebutkan bahwa keluarga berkualitas adalah keluarga yang dibentuk berdasarkan perkawinan yang sah dan bercirikan sejahtera, sehat, maju, mandiri, memiliki jumlah anak ideal, berwawasan ke depan, bertanggungjawab, harmonis dan bertaqwa kepada Tuhan Yang Maha Esa.

Baik keluarga sejahtera maupun keluarga berkualitas, mendapatkan tantangan yang sangat signifikan saat pandemi Covid-19. Hal ini disebabkan karena pandemi yang berkepanjangan telah menghilangkan kesempatan kerja anggota keluarga. Banyak diantara mereka yang terkena dampak pandemi, seperti pemutusan hubungan kerja (PHK) besarbesaran. Terlebih anggota keluarga yang terkena PHK adalah tulang punggung penghasil rejeki buat keluarganya.

Pemenuhan hidup sehari-hari, mulai dari sembako, tuntutan anak sekolah, membayar kredit, membayar listrik, air, telepon dan sebagainya, secara perlahan telah menurunkan kemampuan dan daya beli anggota keluarga. Dampak selanjutnya, adalah menurunnya status gizi keluarga terutama balita dan anak-anak. Menurunnya mutu pendidikan, meningkatnya permasahalan sosial dan angka kriminalitas. Oleh karena itu, peran aktif intsitusi keluarga sangat dibutuhkan sehingga secara perlahan, keluarga dapat mengatasi persoalan ekonomi keluarga, agar dapat bangkit lagi di tengah pandemi covid-19 yang melanda dunia.

\section{Pembahasan}

Sebelum melakukan penelitian fungsi keluarga yang dikaitkan dengan pandemi Covid19, penulis terlebih dahulu melakukan studi pustaka terhadap jurnal ilmiah dari berbagai sumber bacaan yang ada.

Nunung Sri Rochaniningsih, dalam tulisannya yang berjudul, "Dampak Pergeseran Peran dan Fungsi Keluarga Pada Perilaku Menyimpang Remaja”, hasil penelitiannya menyatakan bahwa sebagian besar remaja telah melakukan hubungan seks pranikah. Maraknya perilaku menyimpang di kalangan remaja terjadi karena tidak berfungsinya sistem sosial di dalam keluarga dan ketidakharmonisan hubungan anak dengan orang tua. Beberapa peran dan fungsi dalam keluarga telah mengalami pergeseran seiring perkembangan zaman. Oleh karena itu perlu diupayakan bagaimana caranya untuk membangun kembali peran dan fungsi tersebut dalam keluarga.

Hasil penelitian Ekawati Sutikno, yang berjudul "Hubungan Fungsi Keluarga dengan Kualitas Hidup lansia", menyimpulkan bahwa ada hubungan positif yang sangat kuat antara fungsi keluarga dan kualitas hidup lansia. Dokter keluarga disarankan untuk memberikan informasi dan edukasi kepada keluarga untuk meningkatkan fungsi keluarga..

Selanjutnya, Tin Herawati dalam tulisannya yang berjudul "Faktor-Faktor Yang Mempengaruhi Pelaksanaan Fungsi Keluarga Di Indonesia", menyimpulkan bahwa responden terbanyak berusia dewasa akhir dan pendidikan sekolah dasar. Fungsi agama, ekonomi dan lingkungan adalah fungsi yang paling banyak diketahui responden, sedangkan proporsi 
responden terbanyak mengetahui mengenai kependudukan berada kategori tinggi. Temuan menariknya adalah keluarga yang tinggal di perdesaan memiliki fungsi keluarga yang lebih baik dibandingkan dengan yang tinggal di perkotaan. Faktor yang berpengaruh signifikan terhadap pelaksanaan fungsi keluarga adalah usia, status perkawinan, status pekerjaan, tingkat pendidikan, pengetahuan fungsi keluarga, dan akses informasi. Hasil penelitian ini merekomendasikan perlunya sosialisasi fungsi keluarga secara intens ke sasaran utama program yaitu keluarga yang tinggal di perkotaan, keluarga pasangan usia muda, dan keluarga dengan tingkat pendidikan rendah.

Berbeda dengan tulisan jurnal terdahulu, penulis melakukan studi kepustakaan untuk mengetahui penguatan fungsi keluarga di era pandemi covid-19.

Dalam kehidupan berkeluarga, setiap anggotanya menginginkan terjadinya keharmonisan, kebahagiaan dan keseimbangan. Hal ini sesuai dengan teori Talcot Parson yang terkenal dengan teori struktural fungsional (Gorge Ritzer \& Douglas J. Goodman dalam Maknunah : 2017). Menurut teori ini, terdapat empat fungsi penting keluarga yang dikenal dengan skema AGIL. Melalui AGIL ini kemudian dikembangkan pemikiran mengenai struktur dan sistem. Pertama, Adaptation yang artinya bahwa sebuah keluarga harus dapat beradaptasi dengan lingkungan dimana mereka berada. Keluarga harus beradaptasi dengan aturan atau sistem yang ada di lingkungan tersebut. Pada masa pendemi saat ini, keluarga diharapkan bisa beradaptasi dengan era normal baru (new normal). Kedua, Goal yang artinya bahwa sebuah keluarga memiliki tujuan yang ingin dicapai bersama-sama dengan anggota keluarga lainnya. Tujuan sebuah keluarga dibangun adalah untuk mewujudkan keluarga sukinah, dimana anak-anak yang lahir telah direncanakan sebelumnya. Setelah besar menjadi anak memiliki budi pekerti luhur, cerdas, mandiri dan bertanggungjawab. Ketiga, Integration yang artinya bahwa segala yang ada di dalam sebuah keluarga harus memiliki hubungan saling menyesuaikan atau mengendalikan agar tetap dalam sistem yang memiliki fungsi. Keempat, Latency yang artinya bahwa dalam keluarga, segalanya harus saling melengkapi, memelihara dan memperbaiki agar sesuai dengan sistem. Indikator ketahanan keluarga berdasarkan nilai dan fungsi keluarga dibedakan menjadi tiga kategori, yaitu ; ketahanan fisik, ketahanan sosial dan ketahanan psikologis.

Keluarga berkualitas yang diinginkan baru akan dapat dicapai, kalau setiap keluarga dapat menjalankan fungsi-fungsi keluarga dengan sebaik-baiknya. Fungsi keluarga adalah ukuran dari bagaimana sebuah keluarga beroperasi sebagai unit dan bagaimana anggota keluarga berinteraksi satu sama lain. Hal ini mencerminkan gaya pengasuhan, konflik keluarga dan kualitas hubungan keluarga.

Menurut PP No 21 Tahun 1994 dan BKKBN : 2013, fungsi-fungsi keluarga itu ada 8 (delapan). Kedelapan fungsi-fungsi keluarga tersebut adalah :

1. Fungsi keagamaan.

2. Fungsi sosial budaya

3. Fungsi cinta dan kasih sayang

4. Fungsi sosialisasi dan pendidikan

5. Fungsi perlindungan

6. Fungsi reproduksi

7. Fungsi ekonomi

8. Fungsi pembinaan lingkungan

Fungsi keagamaan merupakan tempat pertama seorang anak untuk mengenal, menanamkan dan menumbuhkan serta mengembangkan nilai-nilai agama sehingga menjadi insan-insan yang agamis, berakhlak baik dengan keimanan dan ketakwaan yang kuat kepada Tuhan Yang Maha Esa.

Fungsi sosial budaya, memberikan kesempatan kepada seluruh anggota keluarganya dalam mengembangkan kekayaan sosial budaya bangsa yang beraneka ragam dalam satu kesatuan. Fungsi cinta dan kasih sayang, dapat memberikan landasan yang kokoh terhadap hubungan suami istri, orang tua dengan anak-anaknya, anak dengan anak serta hubungan 
kekerabatan antar generasi sehingga keluarga menjadi tempat utama bersemainya kehidupan yang penuh cinta kasih, lahir dan batin.

Fungsi perlindungan mengamanatkan bahwa keluarga merupakan tempat berlindung anggotanya dalam menumbuhkan rasa aman dan tentram serta kehangatan bagi setiap anggota keluarganya. Fungsi reproduksi merupakan fungsi dalam perencanaan untuk melanjutkan keturunannya yang sudah menjadi fitrah manusia sehingga dapat menunjang kesejahteraan umat manusia secara universal. Fungsi sosialisasi dan pendidikan, memberikan arti bahwa keluarga adalah tempat pertama dan utama agar anak-anak mendapatkan pendidikan yang baik. Disamping itu fungsi ini memberikan peran dan arahan kepada keluarganya dalam mendidik keturunannya sehingga dapat menyesuaikan kehidupannya dimasa mendatang yang sangat dinamis.

Fungsi ekonomi, merupakan salah satu fungsi penting keluarga. Karena hampir semua kegiatan atau aktifitas keluarga dan anggotanya memerlukan dukungan keuangan. Maka, keluarga hendaknya menjadi pilar penting untuk menjadi penyangga ekonomi, demi keberlangsungan kehidupan keluarga dan keturunannya.

Fungsi pembinaan lingkungan memberikan kemampuan kepada setiap anggota keluarganya, sehingga dapat menempatkan diri secara serasi, selaras dan seimbang sesuai dengan daya dukung alam dan lingkungan yang setiap saat selalu berubah.

Sementara, menurut WHO (BKKBN : 2008), fungsi keluarga terdiri dari :

a. Fungsi biologis, meliputi : fungsi untuk meneruskan keturunan, memelihara dan membesarkan anak, memelihara dan merawat anggota keluarga, serta memenuhi kebutuhan gizi keluarga.

b. Fungsi psikologis, meliputi : fungsi dalam memberikan kasih sayang dan rasa aman, memberikan perhatian diantara anggota keluarga, membina pendewasaan kepribadian anggota keluarga serta memberikan identitas keluarga.

c. Fungsi sosialisasi meliputi : fungsi dalam membina sosialisasi pada anak, meneruskan nilai-nilai keluarga dan membina norma-norma tingkah laku sesuai dengan tingkat perkembangan anak.

d. Fungsi ekonomi meliputi : fungsi dalam mencari sumber-sumber penghasilan, mengatur penggunaan penghasilan keluarga dalam rangka memenuhi kebutuhan keluarga, serta menabung dalam rangka memenuhi kebutuhan keluarga di masa yang akan datang.

e. Fungsi pendidikan, meliputi : fungsi dalam mendidik anak sesuai dengan tingkat perkembangannya, menyekolahkan anak agar memperoleh pengetahuan, keterampilan dan membentuk perilaku anak sesuai dengan bakat dan minat yang dimilikinya serta mempersipakan anak dalam memenuhi peranannya sebagai orang dewasa untuk kehidupan dewasa di masa yang akan datang.

Saat ini, kehidupan keluarga sedang menghadapi tantangan dengan adanya pandemi covid-19. Dikutip dari laman covid19.go.id, pada tanggal 16 Mei 2021, ditemukan data sebagai berikut : jumlah kasus aktif 90.800 (5,22 \%), penambahan kasus positif 3.080, jumlah kasus sembuh 1.600.857 (92,02 \%) dan jumlah kasus meninggal $48.093(2,76 \%)$. Ini artinya penanganan virus corona tetap terus dilakukan dengan serius, melalui tahapan pencegahan (preventif) maupun penyembuhan (kuratif). Penyembuhan cendrung dilakukan oleh tenaga kesehatan, sedangkan pencegahan dapat dilakukan dengan memaksimalkan peran keluarga.

Keluarga adalah lembaga sosial dasar darimana semua lembaga atau pranata sosial lainnya berkembang. Di masyarakat manapun di dunia, keluarga merupakan kebutuhan manusia yang universal dan menjadi pusat terpenting dari kegiatan dalam kehidupan individu. Keluarga terdiri dari pribadi-pribadi yang merupakan bagian dari jaringan sosial yang lebih besar. Oleh karena itu tugas-tugas keluarga merupakan tanggung jawab langsung setiap pribadi dalam masyarakat. Ciri utama dari sebuah keluarga adalah bahwa fungsi utama dari keluarga dapat dipisahkan satu sama lain (Goode : 2007). Terlaksananya fungsi-fungsi keluarga tersebut akan menjadi landasan kuat bagi pembangunan keluarga Indonesia. 
Menurut BKKBN pembangunan keluarga adalah upaya mewujudkan keluarga berkualitas yang hidup dalam lingkungan yang sehat. Keluarga merupakan lingkungan yang pertama dan utama bagi perkembangan individu, karena sejak kecil anak tumbuh dan berkembang dalam lingkungan keluarga. Banyaknya anggota keluarga Indonesia yang terpapar virus corona, memberikan pengertian kepada kita, bahwa saatnya memahami kembali lembaga terkecil dalam masyarakat yang bernama keluarga, serta merevitalisasi kembali fungsi-fungsi keluarga untuk keselamatan semua anggota keluarga dari paparan virus corona. Terlebih di dalam keluarga, mungkin terdapat lansia, bayi dan anak, juga kemungkinan ada keluarga yang sakit dan ibu hamil, tentu rentan sekali terpapar virus corona. Penguatan fungsi keluarga menjadi niscaya.

Menurut Dilworth-Anderson, Burton, and Klein (dalam Kitchen : 2016) struktur fungsional dalam keluarga adalah bagaimana sebuah struktur sosial (keluarga) mampu berinteraksi dan mencapai tujuan bersama. Maka dapat dijelaskan bahwa struktur fungsional dalam keluarga merupakan keragaman peran dan fungsi dalam struktur keluarga untuk mencapai tujuan bersama.

Dalam menjalankan sebuah keluarga, terdapat landasan teori yang dapat menjadi acuan. Teoriteori tersebut dibagi ke dalam dua lingkup utama, yaitu mikro dan makro. Menurut (Puspitawati 2013) ruang lingkup mikro yaitu : teori pertukaran sosial. Sedangkan ruang lingkup makro yaitu : teori struktural fungsional, teori sosial konflik, teori feminis, teori gender, dan teori perkembangan. Secara fungsional, keluarga memiliki fungsi tersendiri.

Fungsi keluarga adalah ukuran dari bagaimana sebuah keluarga beroperasi sebagai unit dan bagaimana anggota keluarga berinteraksi satu sama lain. Fungsi keluarga mempengaruhi kapasitas kesehatan dan kesejahteraan seluruh anggota keluarga. Fungsi-fungsi keluarga tersebut agar dilakukan penguatan kembali pada seluruh anggota keluarganya pada pandemi Covid-19 ini. Contoh penguatan fungsi-fungsi keluarga tersbut, dapat dijelaskan sebagai berikut :

Fungsi agama menekankan pada kejujuran hati kita, bahwa setiap manusia adalah mahakarya Tuhan Yang Maha Esa. Sehingga sudah selayaknya mantaati apa yang diperintahkan-Nya, serta manjauhi larangan-Nya. Presiden Joko Widodo, pada awal pandemi sudah mengingatkan, bahwa saatnya bekerja dari rumah, belajar dari rumah dan beribadah dari rumah.

Fungsi sosial budaya, berarti kita mengajarkan anggota keluarga, bahwa budaya nasional berasal dari akar budaya daerah. Maka budaya daerah di negeri kita harus dilestarikan dengan sebaik-baiknya. Pada adaptasi kebiasaan baru, kebiasaan baik yang sudah dilakukan agar diteruskan, menjadi budaya baru, seperti kebiasaan berjemur pagi, kebiasaan jalan sehat, kebiasaan pakai masker, cuci tangan dan jaga jarak, hendaknya dijadikan seperti budaya seharihari.

Fungsi cinta kasih, mengandung arti bahwa setiap anggota keluarga hendaknya saling menyayangi, saling memaafkan, dan saling memberi dorongan pada masing-masing anggota keluarga agar terhindar dari paparan virus corona. Puisi Dorothy Nolty sangat benderang menginisiasi fungsi cinta kasih, "kalau anak dibesarkan dengan cinta kasih, dia belajar mengasihi diri sendiri dan orang lain". Pada adaptasi kebiasaan baru, antar keluarga hendaknya lebih erat bisa menumbuhkan rasa cinta kasih sayangnya. Mengendalikan marah, rendah hati adalah wujud kasih saying dalam keluarga.

Fungsi perlindungan, memberikan arti bahwa tiap anggota keluarga harusnya saling melindungi. Jangan sampai mereka yang ke luar rumah, saatnya pulang ternyata mambawa virus. Anggota keluarga lain yang tinggal di rumah, tiba-tiba terpapar covid-19. Orang tua hendaknya menjadi suri tauladan untuk anak-anaknya. Stay at home merupakan cara perlindungan dalam bentuk lain.

Fungsi reproduksi. Di era pandemi sebaiknya tunda kehamilan, hindari kehamilan tidak diinginkan (KTD). Supaya berkurang angka kematian ibu (AKI) dan angka kematian bayi (AKB). Juga, agar berkurang angka kesakitan reproduksi, seperti penyakit menular seksual (PMS), HIV/AIDS dan narkoba. 
Fungsi sosialisasi dan pendidikan. Rumah adalah sekolah pertama untuk anak-anak. Orang tua adalah guru pertama dan utama bagi anak-anak. Dampingi anak belajar daring. Saatnya orang tua bersinergi dan mengambil peran seperti guru, sehingga orang tua lebih dekat dengan anak-anak, sebagai awal yang baik untuk meningkatkan hubungan edukatif anak dengan orangtua.

Fungsi ekonomi. Tiap keluarga hendaknya menyesuaikan pengeluaran rumah tangganya. Membeli hanya yang dibutuhkan, menunda apa yang diinginkan, seraya terus berupaya mencari terobosan dan peluang untuk mewujudkan sumber ekonomi baru bagi anggotanya.

Fungsi pemeliharaan lingkungan. Memelihara dan menanam bunga, berkebun, melaksanakan hobi di rumah, menanam bumbu-bumbuan dalam pot atau di pekarangan. Bisa jadi alternatif pada adaptasi kebiasaan baru ini. Lingkungan merupakan tempat dari mana insan manusia tumbuh dan berkembang. Menyapu, memilah sampah organik dan non organik, bisa jadi menjadi langkah nyata dan sederhana dalam memelihara lingkungan. Lingkungan hijau, akan berguna mengubah karbindioksida menjadi oksigen yang sangat manusia butuhkan. Mudah-mudahan lebih erat silahturahmi antar keluarga. Setelah beraktifitas, kembalilah kepada keluarga. Sepenggal puisi dari sinetron Keluarga Cemara di masa lalu, mengingatkan kita akan arti penting keluarga, bahwa "harta yang paling berharga adalah keluarga"

\section{KESIMPULAN}

Dari pembahasan yang sudah dilakukan di depan maka dapat diambil kesimpulan penelitian sebagai berikut :

1. Bahwa pandemi Covid-19 saat ini masih terus terjadi, merambah berbagai negara di dunia. Menyebabkan kematian masyarakat atau dari anggota keluarga dan dari berbagai kalangan dan usia.

2. Bahwa keluarga memiliki peran penting dalam meminimalisir keterpaparan dari virus corona tersebut, dengan menguatkan fungsi-fungsi keluarga yang meliputi fungsi keagamaan, fungsi sosial budaya, fungsi cinta dan kasih sayang, fungsi sosialisasi dan pendidikan, fungsi reproduksi, fungsi ekonomi, fungsi perlindungan dan fungsi pemeliharaan lingkungan.

3. Keluarga dan tenaga kesehatan dapat saling bersinergi mencegah dan menangani Covid19. Keluarga ada pada garda terdepan untuk pencegahan (preventif), sementara tenaga kesehatan ada pada garda terdepan untuk penenganan (kuratif)

\section{DAFTAR PUSTAKA}

Adibah., Z, Ida. (2017). Struktural Fungsional Robert K. Merton: Aplikasinya Dalam Kehidupan Keluarga. Jurnal Inspirasi 1 (2).

BKKBN. (2008). Bunga Rampai Gerakan KB Nasional Mewujudkan Keluarga Kecil Bahagia Sejahtera. Jakarta : BKKBN

BKKBN. (2013). Buku Pegangan Kader Tentang Delapan Fungsi Keluarga. Jakarta : Direktorat Bina Ketahanan Remaja.

BKKBN. (2017). Penanaman dan Penerapan Nilai Karakter Melalui 8 Fungsi Keluarga. Jakarta : BKKBN.

Goode, Willian J. (2007). Sosiologi keluarga. Jakarta: Bumi Aksara.

H, Tin. (2020). Faktor-Faktor Yang Mempengaruhi Pelaksanaan Fungsi Keluarga Di Indonesia. Jurnal Ilmu Keluarga dan Konsumen. Vol 13 No 3

Kitchen, Deeb Paul. (2016). Structural Functional Theory. Encyclopedia of Family Studies: 17.

M, Ainun. (2017). Pelaksanaan Fungsi Keluarga : Studi Kasus Pelaksanaan Fungsi Keluarga Pada Suami Pelaku Poligami Di Kecamatan Kerumutan Kabupaten Pelalawan. Oleh: Jom Fisip Vol. 4 No. 2. 
Peraturan Pemerintah (PP) (1994) No. 21 tentang Penyelenggaraan Pembangunan Keluarga Sejahtera.

Puspitawati, Herien. (2013a). Konsep, Teori Dan Analisis Gender Ekologi Manusia. Vol 2: 113.

S, Ekawati. (2011). Hubungan Fungsi Keluarga dengan Kualitas Hidup lansia. Digital Library : Universitas Sebelas Maret tahun 2011

S, Nunung Rochaniningsih. (2014). Dampak Pergeseran Peran dan Fungsi Keluarga Pada Perilaku Menyimpang Remaja. Jurnal Pembangunan Pendidikan Vol. 2 No. 1.

Undang-undang Nomor 52 tahun 2009 tentang Perkembangan Kependudukan dan Pembangunan Keluarga. BKKBN 